\title{
Reputation Management Capabilities as Decision Rules*
}

\section{Pursey P. M. A. R. Heugens, Gees B. M. van Riel and Frans A. J. van den Bosch}

Utrecht University; Erasmus University Rotterdam; Erasmus University Rotterdam

ABSTRACT We draw on a detailed grounded theory study of the reactions of Dutch food firms to the recent introduction of genetically modified foods to inductively identify the capabilities that firms develop in response to reputational threats. Central to the view on capabilities we propose are the decision rules organizations use to link individual actions to organizational outcomes. Four reputation management capabilities were identified, which were aimed at, respectively: (1) engaging in a cooperative dialogue with relevant stakeholders; (2) presenting the organizational point of view favourably in the eyes of external beholders; (3) avoiding organizational 'ownership' of critical reputational threats; and (4) communicating meaningfully with affected parties, even under conditions of high adversity and time-pressure.

\section{INTRODUGTION}

Which types of systematic internal responses do organizations develop to protect themselves against the impact of reputational threats? Do all organizations rely on a singular response mechanism or do some draw on a greater repertoire of responses? Two intertwined trends have meant that these questions are now more salient than ever before. On the one hand, academics and practitioners alike are starting to recognize corporate reputation - the relative standing of an organization amongst its peers as perceived by its stakeholders ${ }^{[1]}$ - as one of the most precious resources available to organizations (Fombrun, 1996; Fombrun and van Riel, 2004; Hall, 1992; Kay, 1993; Whetten and Mackey, 2002). On the other, the business world has recently been confronted with reputational threats in unprecedented numbers and of an unparalleled impact. ${ }^{[2]}$ In this paper we address the aforementioned questions by inductively developing a theory of reputation man-

Address for reprints: Pursey P. M. A. R. Heugens, Utrecht School of Economics, Utrecht University, Vredenburg 138, 3511 BG Utrecht, The Netherlands (p.heugens@econ.uu.nl). 
agement capabilities - coherent sets of decision rules that allow an organization to protect or improve upon its relative standing amongst its peers as perceived by its stakeholders. Our theory is rooted in a detailed grounded theory study (Glaser and Strauss, 1967) of corporate responses to the reputational threats associated with the recent introduction of genetically modified foods on the European market.

Reputational threats - events or trends that could have a negative impact on an organization's relative status amongst its peers as perceived by its stakeholders if left unattended - usually come in one of two forms: crises or issues. A crisis can be seen as a 'low probability, high impact event that threatens the viability of the organization and is characterized by ambiguity of cause, effect, and means of resolution, as well as by a belief that decisions must be made swiftly' (Pearson and Clair, 1998, p. 60). Alternatively, issues have been defined as 'a gap between the expectations of a stakeholder regarding corporate behavior and the same stakeholder's perceptions of actual corporate behavior' (Nigh and Cochran, 1987, p. 4). Key differences between these two types of reputational threats are that the former are immediate, unexpected, and henceforth open to many kinds of often speculative interpretations (Pearson and Clair, 1998), whereas the latter are slowly evolving, relatively predictably, and often highly politicized in the sense that affected actors are entrenching themselves in rivalling coalitions based on their solution preferences (Lamertz et al., 2003). These differences are not without consequence, because both types of reputational threats play a different role in organizational learning and change processes. Crises represent 'shocks' or 'jolts' that open organizations up to the possibility of change, whereas less immediate issues allow organizations to engage in learning processes like comparing, analysing, explaining and devising analogies. ${ }^{[3]}$ The immanent differences between these two types of reputational threats also stimulate organizations to develop multiple reputation management capabilities, each geared specifically towards crises or issues.

\section{GAPABILITIES AS DEGISION RULES}

What is the essence of organizational capability ${ }^{[4]}$ At the most basic level, this notion entails an organization's ability to accomplish some specific desired result, say: $R$ (Winter, 2000, pp. 981-2). This implies that we can express organizational capability with respect to a certain task as a single dummy variable: either the organization has the $R$ capability and can therefore produce the outcome $\left(X_{R}=\right.$ 1 ), or it lacks such a capability and is thus unable to produce it $\left(X_{R}=0\right)$. In fact, this teleological aspect of organizational capabilities is so commonly accepted that most capabilities are denoted by the organizational outcome they are meant to produce, such as: marketing capabilities (Day, 1994), leadership capabilities (Useem and Harder, 2000), and information systems capabilities (Feeny and Willcocks, 1998). Teleology is thus central to the concept of capability, but at the 
same time it remains somewhat gratuitous to operationalize capabilities by the results they are supposed to generate - simply because this does not tell us anything about what actually produced the desired organizational outcome $R$ (Priem and Butler, 2001). To uncover the true essence of organizational capability, we must therefore establish a plausible chain of events that demonstrates how $R$ could have been obtained.

Organizational scholars leave little room for doubt as to where this causal chain should begin: they hold that all organizational outcomes somehow start with individual action (Cyert and March, 1963; March and Simon, 1958; Thompson, 1967). Karl Weick puts it as follows: 'Whenever organizations act - the university gave tenure, the government negotiated, the bakery searched its memory, the orchestra enacted chaos - people act. And any assertion that organizations act can be decomposed into some set of interacts among individuals such that if these people had not generated and meshed a specific set of their actions, . . then the organization would not have performed the act attributed to it' (1979, p. 34). The implications of this view for a theory of organizational capability are clear: such a theory should firmly be rooted in the acts of individuals. But what connects individual actions to organizational outcomes?

\section{Rules in Organizations}

Like a number of influential scholars before us, we propose that in most organizations decision rules - normative constraints that guide the behaviour of individuals by determining the relative appropriateness of all the behavioural options open to them ${ }^{[5]}$ - constitute the primary device for linking the acts of individual members to organizational results such as $R$. Weick, for example, writes that all organizations require 'assembly rules' by which individual behaviours are 'assembled and sequenced to produce an outcome' (1979, p. 35). Furthermore, Pentland relies on so-called 'grammatical rules' to 'describe the sequences of actions that make up organizational processes' (1995, p. 552). In an analysis of how 'formal rules' govern life in an American research university, March et al. similarly observe that 'human actions are organized around rules, and these rules fit together to create and maintain social systems' (2000, p. 7). As a final example we point at DiMaggio and Powell who hold that 'organized life is explicable' due to 'institutional rules' that 'constrain individual behaviour by rendering some choices unviable, precluding particular courses of action, and restraining certain patterns of resource allocation' (1991, pp. 9-10). In brief, decision rules form an indispensable aspect of organizational capability because they connect individual actions to organizational outcomes. But how do decision rules make this connection?

In order to facilitate organizational action, decision rules must perform three elementary functions. First, they must overcome bounded rationality problems (Simon, 1955) that impede the decision-making faculties of individual organiza- 
tion members by removing as much as possible the element of active deliberation from their task-related decisions. Rules 'cut the Gordian knots' of decision making (Perrow, 1972, p. 31) by excluding the particular merits of particular cases from practical consideration through an a priori specification of what is to be done regardless of the circumstances of particular cases (Warnock, 1971). Second, decision rules must offer a remedy to the 'problem of the utilization of knowledge not given to anyone in its totality' (Hayek, 1945, p. 520). The achievement of complex organizational results requires the simultaneous or sequential execution of many individual acts, but this synchronized deployment is hampered by the fact that organizations are distributed knowledge systems lacking an overseeing 'mind' (Tsoukas, 1996). Organizations must therefore rely on decision rules for concerting the efforts of multiple collaborating or interdependently operating specialists (Grant, 1996a, 1996b). Third, decision rules must help organizations solve the problem of delegating tasks under the condition of incomplete alignment of interests between the organization and its members (Jensen and Meckling, 1976). Decision rules can be used to expose individuals to incentives that appropriately induce them to operate in the organization's interest (Prendergast, 1999). The following three sections describe at greater length how decision rules connect individual action to organizational outcomes by overcoming these three fundamental problems.

\section{Decision Rules and the Problem of Bounded Rationality}

A theory of organizational capability has to be rooted in a view of individual behaviour that is compatible with the access to information and the computational capacities individuals possess in the organizational environment in which they have to operate (Simon, 1955, pp. 99-100). We know that the decision-making ability of human beings is subject to both limitations and systematic biases (Tversky and Kahneman, 1974), but this is not a problem per se. Problems only start to arise when individuals are put in a setting where the complexity of the decisions they have to make greatly outweighs their cognitive capacities - like in modern organizations. Three interrelated aspects of modern organizations in particular make them particularly inhospitable territory for the boundedly rational decision maker. First, organizations have a strong tendency towards knowledge ossification (Berman et al., 2002, p. 17) - the routinization of decision processes that were once deliberate. Ossification processes mean that individuals gradually grow unaware of the decisions underlying their actions, which means that certain behaviours in organizations can long outlive their reasons for being. Second, employees may have multiple beliefs about the nature of organizational means-ends relationship without ever being able to know which of these beliefs is most justified (Weick, 1979). Finally, it may well be that organizational outcomes are not being produced by a simple and confined set of antecedents, but by literally hundreds 
or thousands of complexly interconnected organizational factors (Dierickx and Cool, 1989).

To overcome the bewilderment and potential paralysis associated with a mismatch between environmental complexity and decision-making faculties, organizations must deliver their constituents from the ordeals of choice-based action (Cyert and March, 1963). Such deliverance requires the stipulation of clear decision rules that accommodate the impaired decision-maker by specifying ex ante how that individual is supposed to act, whether or not there is a good reason to act as such in every case that may be encountered. This allows individuals to root their behaviour in a decision logic that is neither wilful nor consequential in the normal sense - the logic of appropriateness (Cyert and March, 1963). This decision logic does not require individuals to anticipate the consequences of all behavioural options open to them, but merely asks them to follow a set of rules telling them which of these options are more appropriate than the others (March, 1994). Hence, by engaging in a certain course of action individuals do not signal any attempt to maximize their expected utility, but rather demonstrate their willingness to fulfil the duties assigned to them by some central administration (March and Olson, 1984). Such rule-following in accordance with the logic of appropriateness is central to the theory of organizational capability we propose here, because a view on how the problem of bounded rationality can be overcome represents an important first step toward an explanation of how individual actions are linked to organizational outcomes.

\section{Decision Rules and the Problem of Goordination}

Overcoming the problem of bounded rationality by allowing individual constituents to operate under the logic of appropriateness is a necessary first step towards an explanation of how organizational outcomes are facilitated by means of decision rules, but by itself not a sufficient one. This is because organizations are, in the words of Tsoukas, 'distributed knowledge systems' (1996, p. 13) in the sense that they must somehow utilize knowledge that is widely dispersed over many individual specialists and that cannot be known or controlled by any individual mind. In other words, telling organizational members what to do individually without making an effort to synchronize or otherwise purposefully mesh their joint knowledge and activities into an integrated whole is unlikely to result in satisfactory organizational outcomes. An observation of this kind has led Robert Grant to state that 'the fundamental task of organization is to coordinate the efforts of many specialists' (Grant, 1996a, p. 113; see also Demsetz, 1991). In our view, decision rules play a crucial role in helping organizations overcome the problem of coordination, because they can act as coordinating mechanisms that integrate the specialist knowledge of many interdependently working individuals without wasting too much of their time on cross-learning and communication. 
Grant (1996a) has identified a number of such coordinating mechanisms, starting with directives. Specialists can efficiently coordinate their efforts with people who are specialists in other fields by giving them direct instructions; this relieves them of the necessity of transferring their knowledge to these individuals by means of a lengthy training process (Demsetz, 1991). A second mechanism is sequencing, which involves organizing work activities chronologically so that each specialist can deliver his or her input to a specific project independently of others (Pentland, 1995). Another option involves the use of routines, which may be defined as 'relatively complex patterns of behavior ... triggered by a relatively small number of initiating signals or choices and functioning as a recognizable unit in a relatively automatic fashion' (Winter, 1986, p. 165). These routines act as catalysts for complex interactions between individuals by increasing the simultaneity of their behaviour, even in absence of significant communication between them ${ }^{[6]} \mathrm{A}$ final mode of coordination is group problem solving, which refers to all forms of task coordination amongst specialists involving consensus-building, personal communication, and cross-learning. Since this latter mechanism is usually very effective but rarely very efficient, Grant (1996a) recommends that this form of coordination be reserved for unusual and complex tasks. These coordinating mechanisms are at the core of the theory of organizational capability we introduce here, because an approach to overcoming the problem of coordination represents an important second step toward an explanation of how individual actions are linked to organizational outcomes.

\section{Decision Rules and the Problem of Delegation}

In our discussion of the problem of bounded rationality, we pointed out that decision-rules allow individuals to operate in a non-calculative way by enabling them to model their behaviour after ethical requirements or norms of appropriateness (Frey, 1998). But Sunstein and Ullmann-Margalit (1999) warn us that the decision to adhere to the logic of appropriateness is not a non-calculative decision but in fact a rational attempt to reduce the problems associated with on-the-spot decision making in a later stage. In other words, the a priori decision to act noncalculatively at a later point in time is a calculative decision, which is made while the individual is still operating under the logic of consequentialism (Cyert and March, 1963). Like the problem of bounded rationality, this is not a problem per se, but it is in fact a problem in modern complex organizations where delegation relationships abound.

Delegation is the hallmark of modern organization; not just delegation between owners and professional managers (Berle and Means, 1932), but also amongst and between managers and employees themselves. Entrusting others with tasks that otherwise would have had to be performed by the self is perhaps the primary mechanism that explains the productivity of the modern firm, because it allows 
the leveraging of the diversity of skills in the organizational arsenal (Jacobides and Croson, 2001). But delegation also creates potential misalignments of interests within organizations, because the delegator and his or her delegatees do not necessarily share common objectives (Eisenhardt, 1989a). This is a problem when delegatees follow the logic of consequentialism to determine whether they should switch to the logic of appropriateness. Given a discrepancy between their private interests and those of the organization, rational deliberation on their part may lead them to the conclusion that it is not in their best interest to blindly follow the decision rules prescribed to them by the organization.

A realignment of interests between delegator and delegatee therefore has to take place before individuals are put in the position where they have to choose between surrendering to the logic of appropriateness and remaining in the deliberative mode of practical reasoning. This realignment can be accomplished by adopting incentive systems - composed of decision rules - that reward individuals for rulefollowing and penalize them for rule-defiant behaviour (Prendergast, 1999). The adoption of such incentive rules represents a third necessary step towards a theory of organizational capability. The three steps we described are jointly sufficient to explain how individual actions are linked to organizational outcomes, because they tell organizational members what to do individually, how to coordinate their efforts with others, and why it is rational for them to do so.

\section{Common Misunderstandings about Decision Rules}

These are the contours of our theory of capabilities as decision rules. But before we proceed by introducing the research project, we will address some common misunderstandings about decision rules, notably that they are necessarily rigid and immanently codified. The persisting idea that rules breed inflexibility probably derives from the influential literature on bureaucratic 'dysfunctions' and 'bureaupathologies' (Blau, 1955; Gouldner, 1954; Merton, 1957). Yet, there is no convincing case to be made for a direct relationship between rule proliferation and organizational obstinacy. In fact, numerous scholars have pointed at the crucial role decision rules play in preserving the adaptability and flexibility of organizations. Eisenhardt and Sull (2001) argue that 'simple rules' provide organizations with the structure to seize business opportunities in turbulent, ever-changing markets. Similarly, Weick (1998) perceives a crucial link between decision rules and improvisation in organizations. According to his view, the idea that improvisation boils down to 'making something out of nothing' is astonishingly incomplete. The true nature of improvisation can only be understood if we acknowledge the fact that successful improvisers are skilled practitioners who create as well as follow rules, such that their activity is controlled but not predetermined. For March (Levitt and March, 1988; March, 1981, 1996), rules are both the medium and the message of organizational learning. Organizational experiences are recorded in rules to 
guarantee their preservation, but such 'etching' of experiences in accessible memory also facilitates their diffusion. People lacking first-hand experience with certain types of problems can benefit from the knowledge of experienced others by applying the rules these experts once recorded. In sum, organizational rules are at the core of various crucial adaptive processes in organizations.

It is also a mistake to presume that organizational rules must necessarily be codified, as many rules in organizations tend to be unwritten. ${ }^{[7]}$ March et al. (2000, pp. 18-19) point out that the distinction between written and unwritten rules is often far from consequential since the commonalities between them are as plentiful as the differences are scarce. First, both types of rules are maintained and communicated through socialization. Second, both written and unwritten rules exist to offset the bounded rationality- and self-interestedness-biases in individual decision makers. Third, in both manifestations rules can be self-enforcing, provided that an actor's compliance is seen as appropriate in the eyes of influential thirdparty observers. Finally, all rules reproduce social structure by accumulating experiences over several generations of rule-followers. Hence, codification is not a necessary characteristic of decision rules.

\section{THE RESEARGH PROJEGT}

The purpose of this paper is to inductively develop a contextually relevant theory of organizational responses to reputational threats, following the procedures suggested by the grounded theory approach (Glaser and Strauss, 1967). These procedures entail a constant comparison between an emerging theory and data throughout the data collection and analysis process. The unfolding theory acts as an interpretative lens that highlights the importance of empirical facts and distinctions, whereas previously gathered data simultaneously focus attention on the theory's adequacy as a framework for capturing the relevant dimensions of the most recent data being collected (Isabella, 1990). The final product of this transient truce between theory and data should be a conceptualization that accounts for all relevant nuances in the data. ${ }^{[8]}$

The empirical basis of this study is a four-year (September 1997-October 2001) qualitative investigation of the reactions of the Dutch food industry to the introduction of genetically modified food ingredients. With the foods themselves often being described as 'Franken-foods' (Miller, 1992), 'Über-plants' (Walsh, 1999), or 'Demon seeds' (The Economist, 1998), this setting easily meets the criteria of an 'extreme case', one in which the need for and the development of reputation management capabilities is more evident and transparent than in other situations (Eisenhardt, 1989b). Conceptually, this study builds on the previously outlined generic theory of organizational capabilities as decision rules, and our ambitions with this theory are two-fold. First, we strive for an application of the generic theory in the hope of demonstrating its relevance. Second, we aim for a contex- 
tualization of the generic framework in order to make it more amenable to the facts of the situation as we found them.

\section{Data Collection}

During the research period, we studied the introduction process of genetically engineered foods in Europe from a variety of different empirical angles. ${ }^{[9]}$ First, to gather firsthand knowledge of the reputation management capabilities of the firms in the Dutch food sector, we conducted so-called focused interviews (Merton et al., 1956) with key players in the biotechnology issue. To obtain data that captured the greatest possible variation in reputation management experiences, we selected a group of 23 key players in the issue, following Glaser and Strauss's (1967) notion of theoretical sampling in terms of theoretical relevance. More specifically, we sought variation with respect to the roles these various participants played in the issue, as indicated by both the nature of the organizations that employed them and by their job titles. A full listing of our interviewees is presented in Table I.

Secondly, we conducted a large-scale archival study to corroborate our interview findings with objectified printed data. We were allowed access to the archives

Table I. Listing of interviewees

\begin{tabular}{|c|c|c|}
\hline Number & Organization & Job title \\
\hline 1. & Product Board for Margarine, Fats, \& Oils & Secretary \\
\hline 2. & Product Board for Margarine, Fats, \& Oils & Policy Director \\
\hline 3. & Product Board for Margarine, Fats, \& Oils & Head of Communications \\
\hline 4. & Product Board for Margarine, Fats, \& Oils & Editor Biotechnology Newsletter \\
\hline 5. & Product Board for Grains, Seeds, \& Legumes & Policy Director \\
\hline 6. & Product Board for Animal Feed & Policy Director \\
\hline 7. & Ministry of Economic Affairs & Coordinator Biotechnology \\
\hline 8. & Ministry of Agriculture & Coordinator Biotechnology \\
\hline 9. & Dutch Standardization Institute & $\begin{array}{l}\text { Standardization Consultant Food and } \\
\text { Agriculture }\end{array}$ \\
\hline 10. & Consumer \& Biotechnology & Policy Director \\
\hline 11. & Consumer's League & Policy Director \\
\hline 12. & Unilever & Issues Manager \\
\hline 13. & Unilever & Purchasing Officer \\
\hline 14. & Unilever & Public Affairs Manager \\
\hline 15. & Numico & Director Corporate Affairs \\
\hline 16. & Shell & Public Affairs Manager \\
\hline 17. & Gist-Brocades & Director of Public Affairs \\
\hline 18. & Gist-Brocades & Senior External Communications \\
\hline 19. & Ahold & Public Affairs Manager \\
\hline 20. & Het Financieele Dagblad & Editor \\
\hline 21. & De Volkskrant & Science Editor \\
\hline 22. & Schuttelaar \& Partners & Communication Advisor \\
\hline 23. & Wageningen Agricultural University & Professor of Mass Communications \\
\hline
\end{tabular}


of the Product Board for Margarine, Fats, and Oils, a semi-public organization that serves the interests of its associated industry members. These archives consisted of a broad array of materials, ranging from letters and faxes to industry crisis plans and consultancy reports. Furthermore, three roundtable discussions were organized, in which we invited both industry and NGO (non-governmental organization) representatives to discuss our initial research findings with us. We were also able to use a collection of audiovisual materials, consisting of every television broadcast on Dutch public television ever devoted to the issue. Finally, we used a number of publicly available resources, such as the Internet, international magazines, and Dutch newspapers as a back-up, to check whether we had missed any significant events.

\section{Data Analysis}

Obviously, these different lines of qualitative inquiry provided us with more data than we could use and interpret directly. We therefore sought for a means to pull the data from these various sources together in a way that would simultaneously further our understanding of the various reputation management capabilities in use and reduce the ever-present danger of 'death by data asphyxiation' (Pettigrew, 1988; cited in Eisenhardt, 1989b). We decided to use vignettes, 'focused description[s] of a series of events taken to be representative, typical, or emblematic in the case [one is] doing' (Miles and Huberman, 1994, p. 81), as our primary tool for data reduction and interpretation.

The vignette strategy served three critical purposes. First, we structured our data collection efforts by using draft versions of these vignettes in the interview process. This stimulated our respondents to talk about salient themes that emerged in earlier interviews, and pre-structured our later interviews to facilitate sorting and coding processes. Second, our vignettes told us when it was time to stop collecting data. After approximately the seventeenth interview a saturation process started to set in (Glaser and Strauss, 1967), after which very few new facts and opinions emerged that otherwise would have forced us to substantially rewrite the vignettes. Third, the little narratives allowed us to validate our research findings by having them reviewed by a number of key informants $(\mathrm{N}=5)$. The rationale behind this tactic is that informants and participants may disagree with the researchers' conclusions and interpretations, but they may as a rule not disagree over the actual facts of the case (Yin, 1994). The reviewers that we used to verify our findings are numbered 1, 2, 5, 13, and 22 in Table I.

\section{FOUR REPUTATION MANAGEMENT GAPABILITIES}

During the research process, a number of qualitatively distinct types of responses to reputational threats emerged from the data inductively. We made constant com- 
parisons between these emerging empirical insights on the one hand, and our generic theory of organizational capability on the other. The initial framework allowed us to ask our respondents more focused questions during the data collection period, whereas the insights we gained from these informants permitted us to apply our framework to the empirical materials we were investigating. This comparative process ultimately resulted in four contextualized versions of our generic framework, each representing a reputation management capability that captured the essence and explained the tinges of a distinct corporate response. We labelled these four capabilities as follows: (1) dialogue, (2) corporate silence, (3) advocacy, and (4) crisis communication.

\section{Dialogue Capabilities}

The first reputation management capability we identified allowed managers to build cooperative and trust-based relationships with a broad range of external constituencies, especially those with non-economic motivations (Heugens et al., 2002; Sharma and Vredenburg, 1998). The managers who took part in the development and implementation of these dialogue capabilities seemed convinced that they had to reach out to the critical stakeholders of their organizations in order to avert the impact of reputational threats. But their jobs were significantly complicated by the excessive complexity of the environment in which they had to operate. Not only were they forced to cope with all the multifaceted aspects of organizational life in general, but also with a multitude of external stakeholders and the often unpredictable interactions amongst those parties (Rowley, 1997).

Given the unusual complexities of their operating environments, it remains questionable whether any of these managers had the deliberative faculties to foresee most of the external dynamics that would arise in response to their attempts at establishing a dialogue. To get their jobs done, many of them therefore switched from a consequential decision-making mode to an approach based on the logic of appropriateness (Cyert and March, 1963). Rather than trying to predict the consequences of every decision they made, they chose to adhere to a set of more concrete decision rules. ${ }^{[10]}$ These rules, for example, specified that managers should organize round-table discussions involving all the stakeholders the company critically depended on. Other rules instructed them to supply key stakeholders with new information that could be of interest to them as soon as the organization had acquired and validated it. Some rules even specified that stakeholder views should be used as direct input for corporate decisions pertaining to the reputational threat at hand. In combination, these rules enabled the managers in our sample to maintain a dialogue with external parties, even if they were unsure at times about the direct results of their actions (see Table II).

In addition to providing a set of behavioural guidelines for the individual specialists to follow, reputation management capabilities should also have a 
Table II. Dialogue capabilities

Vignettes Decision rules Data extracts

Property 1: Individual action

Issues managers tend to believe that engaging in a dialogue with interested or affected outside stakeholders will help their organizations to improve upon their competitive position, reputation, and societal legitimacy. Consequentially, they engage in all sorts of communicative activities such as informing and negotiating with outside stakeholders. In general, issues managers exercising the dialogue capability define their relevant 'target audience' more broadly than those utilizing other capabilities.

\section{Property 2: Coordinating mechanisms}

When managers decide to use a dialogic approach, many of the coordination problems that inevitably arise when multiple specialists work on a complex project simultaneously tend to be resolved in ways that require significant amounts of 'face time'. Experts adjust their activities to those of other specialists by learning from them how they perform their jobs and by teaching them the essentials of their own functions.

\section{Property 3: Incentive systems}

Organizations opting to use a dialogic approach to reputation management tend to encourage behaviour that results in the exchange of information and redistribution of responsibilities across organizational boundaries. They also discourage behaviour that tends to lead to more isolated responses to pressing issues. $\rightarrow$ Organize roundtables for which all relevant parties are invited.

$\rightarrow$ Provide key stakeholders with information proactively.

$\rightarrow$ Co-opt influential outsiders by allowing them joint decisionmaking power.

$\rightarrow$ Meet personally with all the parties that could influence this issue.

$\rightarrow$ Discuss all options that are open to the firm with the dialogue partners.

$\rightarrow$ Aim for consensus on all aspects of the issue that pertain to the organization.

$\rightarrow$ Reward behaviour that promotes better relationships between the organization and its external constituencies.

$\rightarrow$ Penalize behaviour that frustrates the organization's negotiations with outside parties.
'I strongly support the roundtable negotiation model. My Ministry has organized a number of roundtables on biotechnology in the past. (. . .) [Due to the introduction of new crops] the importance of open roundtable discussions will only increase in the future.'

As companies we need to reach out to other parties ourselves. (. . .) We have to make field trips to societal organizations and the government.'

'Through informal consultations we try to inform the societal cadre. (...) We have made specific agreements with certain NGOs to consult them before we go public with any new piece of information.'

'Policy documents are just an outcome. (...) The fact that we have to consult all of the involved parties during the writing process to get their input is of much more value.'

A policy maker at the Product Board for Margarine, Fats, and Oils gets promoted to Permanent Secretary, due to his leading role in the informal consultations (factual example). 
coordination mechanism in place to adjust the efforts of all these individuals to one another. Companies that used the dialogue capability frequently resorted to group problem solving (Grant, 1996a) as a means of overcoming potential coordination problems. Dialogue decision rules dictated that managers should try to meet personally with all the parties that could play a decisive role in the evolution of the reputational threat. Managers also followed guidelines advising them to root all decisions involving multiple parties in consensus, rather than in persuasion or coercion. In other words, the dialogue capability also consisted of an additional set of decision rules stipulating that personal and communication-intensive forms of coordination were most appropriate (see Table II).

Finally, since not every rule stipulated in organizations coheres well enough with the interests of individual managers to be followed spontaneously, organizational capabilities also need to provide and maintain an incentive system that stimulates rule-following behaviour in accordance with the logic of appropriateness. In case of the dialogue capability, these incentives were aimed at increasing the likelihood of managerial behaviour that stimulated better relationships with external parties by rewarding successful attempts at establishing stakeholder dialogue. At the same time, the dialogue incentive system also reprimanded behaviour frustrating the organizational ability to engage in meaningful relationships with outside constituencies (see Table II).

\section{Advocacy Capabilities}

The second reputation management capability we uncovered through the present study was aimed at persuading external audiences that the organizational position on an otherwise controversial issue was both rationally acceptable and morally legitimate. The managers exercising these advocacy capabilities believed that they were justified in using their rhetorical and propagandizing skills to make the organizations they worked for look better in the eyes of external beholders. Again, it must not have been easy for these managers to make reliable estimates of the persuasiveness of their actions, since the effect of advocacy attempts is not only a function of the coherence and compellingness of the corporate message, but also of the number and intensity of dissenting voices in the organizational environment (Grunig and Grunig, 1992).

An important aspect of these advocacy capabilities is therefore that they equipped managers with a number of detailed instructions that enabled them to economize on cognitive effort by allowing them to follow rules in accordance with the logic of appropriateness. Such rules, for example, instructed managers to design and implement responses to reputational threats that sought to legitimize their organizations' production methods and safety standards in the eyes of consumers. Often they hired specialized corporate communication agencies to provide the content for these public affairs campaigns. Other rules informed managers on 
how to deal with the potential impact of national authorities and the EU government on their businesses, and urged them to make extensive use of political marketing tools to present their organizations favourably in these non-market arenas (Harris and Lock, 1996; see Table III).

In addition to instructing individual managers on what to do under which circumstances, advocacy capabilities should also provide a solution to coordination problems that might arise when these professionals try to combine their efforts to resolve joint problems. Since the development of advocacy-oriented responses to reputational threats requires the execution of many interrelated but essentially separable tasks, many organizations using an advocacy approach relied on rules that prescribed sequenced forms of coordination. Advocacy tasks (such as competitive intelligence, market research, campaign strategizing, copy writing, and communication channel management) were typically organized as stand-alone activities, so that small teams of professionals could work on them separately. These activities were also organized in time-patterned sequences, so that the output of one group provided the input for another without there being much need for inter-group communication and adjustment (see Table III).

A final aspect of the advocacy capability is that it should persuade the managers it addresses to follow the behavioural and coordination rules it prescribes. To that end, the capability provides incentives to stimulate behaviour that helps to create a more favourable external image for the organization. At the same time, it puts sanctions on any display of behaviour that could exert a negative influence on outsiders' assessment of the corporation's actions and decisions (see Table III).

\section{Gorporate Silence Capabilities}

A third reputation management capability we identified was aimed at avoiding organizational 'ownership' of the reputational threats generated by the introduction of genetically enhanced foods. For our present purposes, ownership of reputational threats (Oomens and van den Bosch, 1999) may be interpreted as a strong association in the eyes of relevant publics between an organization and a given reputational threat, which could potentially lead to additional responsibilities on behalf of the organization for resolving that threat. The managers using these socalled corporate silence capabilities tried to keep the company name out of the public debate as much as possible, in an attempt to avoid their organization and modern biotechnology always being mentioned in the same breath. The task of maintaining corporate silence is a very complex one, not only since most of the structures and processes determining the course of the public debate are not under corporate control, but also because it is exceptionally difficult to make sure that none of the organization's employees breaks the cordon of silence.

Corporate silence capabilities therefore offer managers practical guidelines in the form of decision rules that minimize the need for on-the-spot decision making 
Table III. Advocacy capabilities

Vignettes Decision rules Interview extracts

Property 1: Individual action

Issues managers assume that it is possible to devise effective strategies for gaining the endorsement of outside parties, even with respect to highly controversial issues. To that end, they develop persuasion-oriented public affairs plans (for which the content is often provided by specialized communication agencies). These plans often have a dual focus on both the market (i.e., consumers and competitors) and non-market arenas (national and supra-national governments) in which the firm competes.

\section{Property 2: Coordinating mechanisms}

If managers decide to adopt an advocacy approach, the bulk of the coordination problems that emerge when many specialists have to work together to solve joint problems are kinked out by means of sequencing activities. Many of the tasks that are required to design and implement public affairs plans are in fact relatively separable (even though they are interdependent and interconnected in many ways). These tasks can therefore be performed in relative isolation in a time-patterned sequence to minimize the need for inter-task coordination and communication. $\rightarrow$ Develop and execute a welldesigned public affairs plan.

$\rightarrow$ Hire internal and external communication experts to present the organization favourably in its market arenas.

$\rightarrow$ Use political marketing strategies to compete better in the non-market arenas of the firm.

$\rightarrow$ Organize the advocacy tasks as stand-alone activities, so that every team of experts can deliver its inputs without having to coordinate them with others.

$\rightarrow$ Organize these activities as overlapping sequences as much as possible to speed up execution time.

$\rightarrow$ If parallel processing is impossible to attain, organize these activities in a timepatterned sequence to minimize interferences.
'Our policy is one of "public education". We publish a lot about modern biotechnology. (. . .) Through the introduction, we try to contribute to the public's knowledge and understanding:'

'The people in Brussels are lukewarm about biotechnology. We invest a lot of time and money in convincing them that what we do is absolutely necessary for the competitiveness of the Union and poses no threat whatsoever to its citizens.'

'Managing the issue of modern biotechnology is primarily a matter of doing your homework thoroughly. Here at [a Dutch biotechnology-driven firm], one set of experts is monitoring continuously what is happening in Brussels and in Strasbourg (...), whereas others are testing and assessing the safety of our products.'

'The aim of my department is to "sell" the new technology to the public by adopting a high profile communications strategy. (. . .) Other departments are [simultaneously] exploring the benefits of genetic modification to make our case more convincing.' 
Table III. Continued

\begin{tabular}{|c|c|c|}
\hline Vignettes & Decision rules & Interview extracts \\
\hline $\begin{array}{l}\text { Property 3: Incentive systems } \\
\text { Many organizations that select the } \\
\text { advocacy approach as their } \\
\text { preferred issues management } \\
\text { strategy explicitly stimulate } \\
\text { behaviour that helps to create a } \\
\text { more favourable impression of their } \\
\text { goals and intentions with outside } \\
\text { audiences. At the same time, these } \\
\text { organizations also put a disincentive } \\
\text { on employee behaviour that thwarts } \\
\text { their favourable external image. }\end{array}$ & $\begin{array}{l}\rightarrow \text { Reward behaviour } \\
\text { that presents the cause } \\
\text { of the organization } \\
\text { more favourably to } \\
\text { external publics. } \\
\rightarrow \text { Penalize behaviour } \\
\text { that has a negative } \\
\text { influence on the } \\
\text { assessment of the firm } \\
\text { in the eyes of critical } \\
\text { constituencies. }\end{array}$ & $\begin{array}{l}\text { Journalists that report favourably } \\
\text { on biotechnology (e.g., describe it } \\
\text { as genetic modification rather } \\
\text { than genetic manipulation) are } \\
\text { 'rewarded' in the sense that they } \\
\text { receive the direct phone numbers } \\
\text { of key corporate officials, which } \\
\text { they can use the next time they } \\
\text { are working on a biotechnology- } \\
\text { related story (factual example). }\end{array}$ \\
\hline
\end{tabular}

in complex situations. Most importantly, these guidelines tell managers to put all external communication tasks in the hands of a relatively small number of welltrained professionals. This centralization rule allows managers to substantially reduce intra-organizational plurivocity (Thachankary, 1992), and hence to promote the organizational point of view in a single, unambiguous voice. Other guidelines supporting the centralization rule prevented non-communication employees from making public statements and directed information-seeking outside parties directly to the communication unit of the organization (see Table IV).

Since corporate silence capabilities depend on the cooperation of many individual specialists for their proper functioning, it is essential that they also offer a solution to coordination problems. The dominant coordination mechanism for this capability consisted of directives - impersonal standards and instructions regulating the interactions between individuals (Van de Ven et al., 1976). To overcome plurivocity, the corporate silence approach first of all required the knowledge of key communication professionals to be codified in handbooks and manuals. These internal regulations specified most of the necessary procedures to be followed for communicating successfully with both employees and outsiders. Furthermore, in most organizations using the corporate silence approach, all employees except for designated communication professionals were explicitly instructed not to communicate with outsiders about current reputational threats. Together, these rules enabled the organization to present a unified view on modern biotechnology to the outside world (see Table IV).

Finally, the corporate silence capability also needs an incentive structure to stimulate corporate employees to follow the specified decision rules. More than any of 
Table IV. Corporate silence capabilities

Vignettes Decision rules Interview extracts

Property 1: Individual action

Managers using the corporate silence approach hope that their attempts to dissociate the names of the companies for which they work from the biotechnology issue will eventually lead to a decreased chance of issue ownership. Their efforts are mainly focused on centralizing the corporate communication function in the hands of a few specialized professionals, in an attempt to present the corporation's views on modern biotechnology as a unified whole, rather than as an uncontrollable amalgam of competing voices.

\section{Property 2: Coordinating mechanisms}

If managers decide to adopt a corporate silence approach, their coordination activities will mainly be focused on silencing voices that deviate from or compete with the organization's official position on the modern biotechnology issue. To accomplish this end, they will codify their expert knowledge in readily accessible materials, and promulgate rules and directives that urge the employees of the organization that are in noncommunication functions to strictly abide by them.

\section{Property 3: Incentive systems}

The incentive system chosen by organizations using a corporate silence approach differs significantly from other issues management incentive systems. Rather than rewarding compliant behaviour, the corporate silence system is much more oriented towards the penalization of deviant behaviour. $\rightarrow$ Make communicating

with outside

constituencies the

exclusive prerogative of

communication

professionals.

$\rightarrow$ Strongly discourage other employees to give their personal opinion about organizational issues in public.

$\rightarrow$ Direct outsiders that request information to the designated communication professionals only.

$\rightarrow$ Codify the knowledge of key communication professionals in issues management plans and communication manuals.

\section{$\rightarrow$ Specify both}

procedures for

communicating with

outsiders as well as

internal lines of communication in these plans and manuals.

$\rightarrow$ Specifically instruct the members of the organization to abide by the rules documented in these plans and manuals.

$\rightarrow$ Reward behaviour that reduces the visibility of the organization with respect to critical issues.

$\rightarrow$ Penalize behaviour that increases the likelihood of issue ownership for the organization.
'I believe that we all should just keep our mouths shut and wait for the day that a product with more benefits [than modified soy] comes along. Until that day, we cannot explain the benefits [of genetic modification] to the public.'

'We don't like to communicate about biotechnology. The public knows that we have a stake in this issue, which could easily give it a wrong impression. (...) Just let the consumer representatives do the talking on biotechnology. Informing the public is their turf.'

'It is an absolute necessity to centralize our information services [with respect to the biotechnology issue]. (...) A decentralized information strategy would be a Public Affairs atrocity.'

'We have written down the lessons that we learned from this first introduction [of genetically altered soy] in what we call our 'charter' [essentially a crisis scenario]. (. . .) We expect our employees to use it for all subsequent introductions.'

The Product Board of Margarine, Fats and Oils (a semi-public organization representing the interests of the Dutch Fats and Oils industry) was endowed with a $€ 350,000$ budget after it had agreed to become the mouthpiece for the industry on biotechnology-related affairs (factual example). 
the incentive systems of the other three reputation management capabilities we encountered, the corporate silence system was oriented towards penalizing deviant behaviour rather than stimulating compliance (Morrison and Milliken, 2000). Employees were certainly rewarded for behaviour that reduced the association between the company and modern biotechnology in the public media, but more telling were the instances in which employees were fined or even demoted after presenting their personal opinion on biotechnology in public (see Table IV).

\section{Crisis Communication Capabilities}

Crisis communication capabilities allow managers to engage in a purposeful exchange of information with interested outside constituencies during immediate reputational threats. Crisis communication is a highly complicated activity because crises usually leave managers with very little time to respond to the challenges and critiques of affected stakeholders. Furthermore, firms struck by an immediate reputational threat are typically affected by a number of conditions that hamper their ability to communicate with outside parties, such as decreased source credibility (because the organization may be tainted by a regrettable event; Leiss, 1994) and receiver problems (because affected non-experts cannot be expected to readily assimilate and understand expert views on what went wrong; Powell and Leiss, 1997). More than any of the other responses to reputational threats, crisis communication capabilities must therefore equip managers with decision rules allowing them to exchange information with affected stakeholders without forcing them to make difficult on-the-spot decisions.

Most of the decision rules we encountered in organizations relying on crisis communication took one of three forms. First, many of the organizations in our sample used rules that stimulated managers to look for 'weak signals' in their external environment (Ansoff, 1980), because these small stimuli could one day evolve into significant reputational threats. Second, these organizations tended to have rules in place that instructed managers how to identify emerging threats rapidly and to interpret them 'on automatic'. This type of automatic crisis identification starts by learning the characteristics of a number of standardized crisis categories and framing new crises in terms of these archetypical classes as they develop (Dutton, 1993). Finally, managers that were frequently involved with crisis communication followed rules that instructed them to match certain crisis categories with standardized, well-learnt responses (Daft and Weick, 1984). In turn, these responses allowed them to communicate purposefully with affected parties in highpressured situations without compromising the organizational position on modern biotechnology (see Table V).

When an organization is confronted with events that require immediate attention, coordination problems easily rise to the fore. Due to the heightened time pressure involved, crisis situations usually rule out all possible forms of coordination 
Table V. Crisis communication capabilities

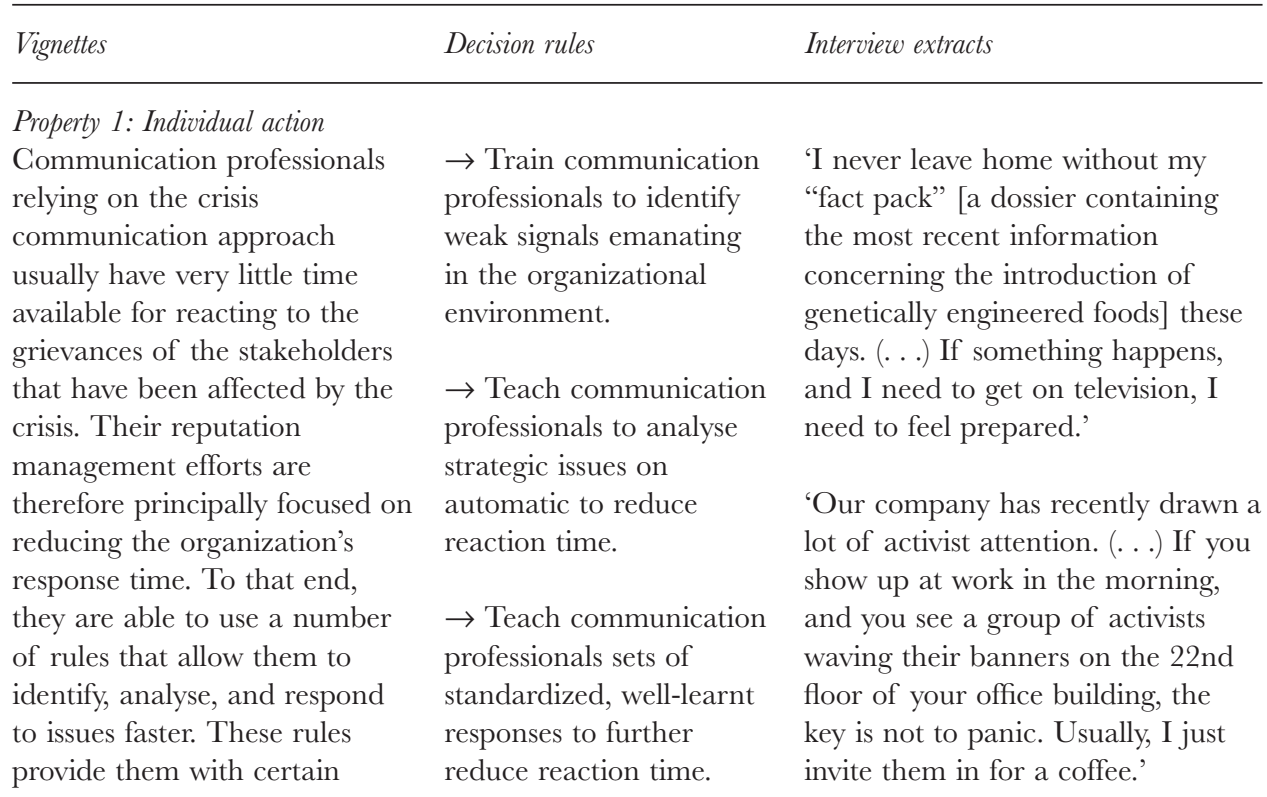

cognitive 'shortcuts' that allow

them to compare new crises

with past learning experiences.

Property 2: Coordinating mechanisms

Since immediate crises are usually characterized by the fact that there is little or no response time available, reputation management specialists in the crisis communication mode cannot rely on forms of coordination that require intensive communication. Effective crisis communication capabilities therefore supply these specialists with decision rules that allow them to adjust their behaviours to one another in a routine fashion, without much need for additional verbal information transfer.

$\rightarrow$ Organize
communication
specialists into relatively
small and stable units to
increase the simultaneity
of their goal-oriented
behaviours.

$\rightarrow$ Empower these groups of specialists sufficiently to facilitate autonomous problem-solving behaviour.

$\rightarrow$ Socialize new group members properly, enabling them to learn and acquire the skills of more seasoned team members.
'Our issues management unit is very small [5 people working at the Dutch headquarters], and we all work on this floor. (. . A) Also, all of our offices have glass walls, so that we can find each other immediately whenever a situation requires our urgent attention.'

'I often compare my [issues management] unit with a swarm of birds. We use each other as our primary set of coordinates. (. . ) That is how we keep track of one another and of the outside world. 
Table V. Continued

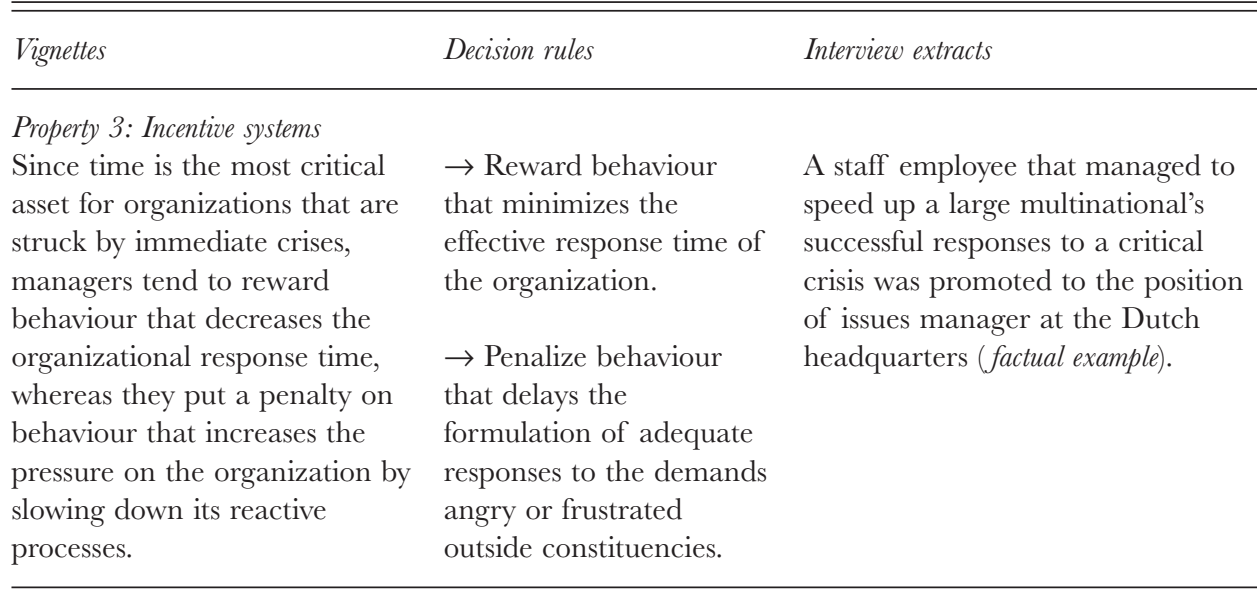

that require intensive communication and face-to-face contact. What is more, crisis situations are often too idiosyncratic and arise too unexpectedly to allow for coordination by means of straightforward standard operating procedures. Therefore, organizations with well-developed crisis communication skills often rely on the routines of their communication specialists as their principal coordination mechanism. To stimulate routine-based task coordination, organizations often allow their reputation management professionals to operate in relatively small and stable groups to stimulate the simultaneity of their actions and decision-making. Because of their relatively high degree of social cohesion, these groups are able to develop the routines that allow them to operate as a single-minded 'pack' when they are put under time pressure (see Table V).

Even though providing professional workers with a large degree of autonomy and the ability to work in small groups can be seen as rewards in and of themselves, many of the organizations that relied on crisis communication capabilities complemented these stimuli with more orthodox incentives. They rewarded individuals who were responsible for implementing innovations that reduced the organization's reaction time with respect to critical reputational threats and penalized employees who caused unnecessary delays in the process of formulating and implementing responses (see Table V).

\section{Gross-Sectional Analysis}

The preceding sections presented the four reputation management capabilities we encountered in our study of the responses of Dutch food firms to the reputational threats imposed by the introduction of genetically enhanced foods. These sections provide us with valuable insights into what capabilities were employed by the firms 
Table VI. Cross-sectional analysis

\begin{tabular}{lrrrrr}
\hline \hline Organization & \multicolumn{1}{c}{ Dialogue } & Advocacy & Corp. silence & Crisis comm. & Total \\
\hline Unilever & $31(48 \%)$ & $11(17 \%)$ & $15(23 \%)$ & $8(12 \%)$ & 65 \\
Numico & $4(14 \%)$ & $7(25 \%)$ & $11(39 \%)$ & $6(21 \%)$ & 28 \\
Ahold & $8(22 \%)$ & $9(25 \%)$ & $12(33 \%)$ & $7(19 \%)$ & 36 \\
Gist-Brocades & $7(18 \%)$ & $13(33 \%)$ & $16(41 \%)$ & $3(8 \%)$ & 39 \\
Prod. Board MFO & $26(44 \%)$ & $10(17 \%)$ & $7(12 \%)$ & $15(26 \%)$ & 58 \\
Prod. Board GSL & $7(54 \%)$ & $0(0 \%)$ & $4(31 \%)$ & $2(15 \%)$ & 13 \\
Prod. Board AF & $5(45 \%)$ & $0(0 \%)$ & $5(45 \%)$ & $1(9 \%)$ & 11 \\
Stand. Institute & $2(22 \%)$ & $0(0 \%)$ & $7(78 \%)$ & $0(0 \%)$ & 9 \\
Total & $90(35 \%)$ & $50(19 \%)$ & $77(30 \%)$ & $42(16 \%)$ & $100 \%$ \\
\hline \hline
\end{tabular}

Notes:

The organizations in this table correspond to those listed in Table I. Included in this analysis are directly involved business firms and their representative organizations. Excluded are firms without a direct stake in the issue, journalists, functionaries from the Ministries of Economic Affairs and Agriculture, NGO representatives, and independent advisors.

The numbers listed in the table correspond to the number of paragraphs from the interview reports in which (elements of) a particular reputation management capability was mentioned. Note that we interviewed several people in some organizations: four at the Product Board for Margarine, Fats, \& Oils; three at Unilever; and two at GistBrocades (currently DSM).

in our sample (cf. research question 1), but they tell us nothing about who used these capabilities in which combinations (cf. research question 2). To address this issue, we will present a brief cross-sectional analysis (see Table VI).

We obtained this analysis by juxtaposing the types of capabilities we uncovered (displayed along the horizontal dimension of Table VI) with the organizations in our sample (comprising the vertical dimension of this table). For the actual analysis, we used the 14 interview reports we obtained from individuals working for these organizations. Each of these reports was systematically and thoroughly examined for evidence of data fitting the four capability categories. In line with a procedure suggested by Isabella (1990), we extracted verbatim sections from these reports (paragraphs in which individuals referred to an element or characteristic of a particular capability), recorded them on separate sheets of paper to represent the core of an individual's statements, and coded them into the final categories. In total, 259 such excerpts were recorded.

The cross-sectional analysis revealed that many organizations relied on multiple reputation management capabilities rather than focusing on a singular response pattern - five organizations used all four capabilities, two organizations used three, and one organization relied on only two capabilities. Overall, the organizations in the sample relied most extensively on dialogue (accounting for 35 per cent of all coded fragments), closely followed by corporate silence (30 per cent). Less popular were advocacy (19 per cent) and crisis communication (16 per cent). But not all organizations in our sample adhere to this pattern. Three of the orga- 
nizations in our sample relied predominantly on dialogue (Unilever, Product Board for Margarine, Fats, and Oils, and Product Board for Grains, Seeds and Legumes), whereas four others were primarily focused on corporate silence (Numico, Ahold, Gist-Brocades, and the Standardization Institute). One organization devoted equal amounts of attention to both capabilities (Product Board for Animal Feed).

But perhaps the most revealing cross-sectional analysis we can perform on this modest data matrix is an investigation of the dominant response pattern of these organizations (operationalized as the specific combination of the two capabilities they use most intensively). Four organizations used a dialogue-corporate silence response pattern (Unilever, Product Board for Grains, Seeds, and Legumes, Product Board for Animal Feed, and the Standardization Institute). We could call this the uncertainty avoider approach to reputation management, because these organizations prefer to secure matters pro-actively through dialogue and eagerly avoid ownership of reputational threats. Three organizations opted for an advocacy-corporate silence response pattern (Numico, Ahold, and Gist-Brocades). This could be called the opportunistic approach to reputation management, because these organizations tend to engage in highly vocal corporate propaganda when the public opinion is temperate, but prefer to take a backbencher's approach when the public debate heats up. Finally, one organization chose to go with a dialogue-crisis communication response pattern (Product Board for Margarine, Fats, and Oils). This could be called the maverick approach to reputation management, because it combines a commitment to pro-active problem-solving through dialogue with a certain disregard for ownership of reputational threats in times of heated public debate.

\section{DISGUSSION}

We have previously discussed a number of rules and the capabilities they constitute as we identified them in the course of our empirical work. But this descriptive-analytical exercise has left three questions unanswered. First, pertaining to the rules, where exactly do they come from? Second, with respect to the capabilities, why do we see differences across organizations in terms of their dominant response patterns? Third, related to both rules and capabilities, what are the limitations of the chosen approach?

\section{Origin of Decision Rules}

The organizational literature provides two complementary views on the origin of decision rules: either rule production is seen as an organization-level phenomenon rooted in learning or as a population-level process grounded in evolution. According to the first perspective, organizational rules are repositories of organizational experiences. Organizations create rules when they encounter new problems that do not seem to be covered by their current repertoire of rules. Rule making 
appears to be a particularly fruitful strategy when such new problems are likely to be fairly recurrent, consequential, or salient (Schulz, 1998). Of course, not all rule creation involves organizational learning (Mills and Murgatroyd, 1991) and not all organizational learning crystallizes in the form of decision rules (March and Olsen, 1988), but a fair amount of all organizational learning consists of encoding inferences from history into decision rules that guide future organizational behaviour (Levitt and March, 1988). The implication of this first view for the present study is that reputation management capabilities can be seen in part as the codified sediment of prior organizational experiences with the management of reputational threats.

Alternatively, the second perspective suggests that rule formation is largely a consequence of population-level ecological or evolutionary processes. Nelson and Winter (1982) have proposed an ecological approach in which organizational routines are analogously seen as genes - path-dependent and relatively inert triggers of action in organizations. The gene metaphor suggests that rule change within organizations tends to be slow relative to the rate of change of the organizational environment. The diffusion of any set of rules across a population of firms can therefore not strictly be perceived as a deliberately adaptive process. Instead, this view suggests that variations in the population-level mix of organizational rules are the outcome of an ecological selection process of differential organizational growth and survival (March, 1996). The implication of this second view is that the reputation management capabilities we identified can in part be seen as the properties of organizations surviving a shakeout process in which firms equipped with inferior capabilities were weeded out.

\section{Differences in Organizational Response Patterns}

Two independent views may explain why we encountered different organizational response patterns: we can either perceive of responses as deliberate and voluntary acts, or as steps that are primarily dictated by the organizational environment (Hrebiniak and Joyce, 1985). The first perspective suggests that organizations experience significant strategic choice (Child, 1972), even when they are faced with reputational threats. This may be the case, for example, when an organization's resource dependencies are not very problematic or when it enjoys an influence over the other organizations in its environment (Emerson, 1962). The strategic choice perspective predicts that the larger, more powerful players in the modern biotechnology issue enjoy considerable slack in terms of choosing their desired response pattern, which implies that they can decide for themselves whether they want to be 'mavericks', 'opportunists', or 'uncertainty avoiders' (see the crosssectional analysis above).

Alternatively, smaller or more dependent organizations are more often forced to comply with the social norms in the industry and adopt only the response 
pattern deemed most appropriate for them by influential observers (Oliver, 1991). Adaptation under these circumstances is mostly determined from without, as the environment weeds out maladapted organizational responses and allows only firms with desired characteristics to remain in business (Aldrich, 1979). The environmental determinism perspective predicts that organizations lacking power or the leverage of critical resources must very carefully match reputation management capabilities with reputational threats. Advocacy and dialogue capabilities can be used for issues, when response time and stakeholder receptivity are in relatively generous supply. When crises break, corporate silence and crisis communication capabilities should be used to minimize the risks of wasting time and galvanizing stakeholders.

\section{Limitations of the Chosen Approach}

The findings and implications of this study must be considered in light of its limitations. One limitation of this study is that it is distinctly organizational - as opposed to strategic - in scope. The study was purposively designed to identify the types of systematic internal responses organizations develop to protect themselves against the impact of reputational threats. No effort was made to link these responses to organizational outcome variables such as financial performance, perceived legitimacy, or corporate reputation. This clearly limits the practical and theoretical implications of this study, as it does not allow us to comment on the relative effectiveness of the individual responses and response patterns we identified. An important avenue for future research could therefore consist of an empirical test of the performance implications for firms confronted with reputational threats of adopting the reputation management capabilities we uncovered.

A second limitation of this study is that it is exclusively based on a grounded theory methodology (Glaser and Strauss, 1967). The main attraction of this approach is that it allowed us to devise 'thick descriptions' of the responses organizations use to withstand organizational threats, which adds to the novelty and insightfulness of our findings by unearthing many contextualized, socially embedded facts. The downside of our choice for grounded theory is that this approach cannot be used to establish the generalizability of our theory of reputation management capabilities as decision rules. An important opportunity for future research could therefore be to develop a large-scale cross-sectional study spanning multiple industries and covering several different reputational threats to assess directly whether our approach is robust enough to explain reputation management in different settings.

\section{GONGLUSION}

A first contribution of this research is that it shows that organizations can develop up to four qualitatively distinct reputation management capabilities in order to 
protect themselves against the impact of reputational threats. Dialogue capabilities allow managers to build cooperative and trust-based relationships with a broad range of external constituencies. Advocacy capabilities enable managers to persuade external audiences that the organizational position with respect to a controversial reputational threat is both appropriate and right. Corporate silence capabilities are aimed at avoiding organizational 'ownership' of critical reputational threats. Finally, crisis communication capabilities allow managers to interact meaningfully with affected parties, even under conditions of high adversity and time pressure.

A second contribution of this paper is that it also shows how the outcomes by which these capabilities are denoted (dialogue, advocacy, etc) are obtained within organizations. We propose that capabilities are composed of decision rules, which fulfil three crucial functions for linking the actions of individual members to organizational outcomes. Rules circumvent the problem of bounded rationality by allowing individuals to make decisions according to the logic of appropriateness rather than the logic of consequentialism. They also solve the problem of coordination by supplying collaborating specialists with a 'grammar' for sequencing and synchronizing their behaviours. Finally, rules offer a remedy for the problem of delegation by aligning the interests of delegator and delegatee before the latter is asked to make any decisions. It is important to note that our grounded theory study of organizational responses to reputational threats has demonstrated the applicability of this behavioural approach to organizational capability, but it has certainly not exhausted future research possibilities in this area. We therefore plea for subsequent studies offering further conceptual refinement and empirical testing of the decision-rule approach to organizational capability.

\section{NOTES}

*We thank Oana Branzei, Hans van Oosterhout, Karen Legge, and two anonymous $\mathcal{F} M S$ reviewers for helping us to improve this paper. Naturally, we assume full responsibility for any remaining errors.

[1] Fombrun and van Riel (1997, p. 10) define corporate reputation as 'a collective representation of a firm's past actions and results that describes the firm's ability to deliver valued outcomes to multiple stakeholders. It gauges a firm's relative standing both internally with employees and externally with its stakeholders, in both its competitive and institutional environments.' The definition we use here is completely in tune with the one proposed by Fombrun and van Riel, but shorter and more focused on the 'relative standing' aspect of corporate reputations.

[2] Consider the following anthology of recent reputational threats: AOL Time Warner's inflation of sales by booking barter deals; Arthur Andersen's shredding of documents after the SEC launched an inquiry into Enron; revenue inflation through 'channel stuffing' at Bristol-Myers Squibb; Coca Cola's bungling with a contamination incident in Belgium; Dow Corning and the issue of leaking breast implants; Enron's use of off-the-book partnerships to hide debts; the insider trading scandal at Martha Stewart Omnimedia; Merck's recording of uncollected consumer-to-pharmacy co-payments; Phillip Morris and the issue of second-hand tobacco smoke; Qwest Communication's inflation of revenue through the use of network capacity 'swaps'; and WorldCom's overstating of its cash flow by booking operating expenses as capital expenses.

[3] We thank an anonymous referee for bringing this point to our attention.

[4] Since an explicit aim of this paper is to inductively develop a specific theory of reputation management capabilities, we need a more generic 'baseline' or 'searchlight' theory of organiza- 
tional capability to guide our observations and interpretations of empirical facts (Popper, 1934/1959). Without some kind of theoretical frame of reference, it would simply be impossible to separate salient from irrelevant observations.

[5] This definition is partially based on Philip Pettit's (1996) definition of rules: 'normative constraints that determine that one member - or perhaps one subset - of a set of options is more appropriate in some way than alternatives' (p. 65). Also see the discussion on the 'logic of appropriateness' (Cyert and March, 1963) in the present paper's section entitled: 'Decision rules and the problem of bounded rationality'.

[6] Examples offered by Grant (1996a) include the routinized behaviour of surgical operating teams and auto racing pit crews. Berman et al. (2002) add the example of teams operating in the National Basketball Association.

[7] Note, however, that unwritten rules are not necessarily tacit in a Polanyian sense (Polanyi, 1962): they are uncodified but not necessarily uncodifiable. This is significant because researchers can then study such rules and put them in print, even if an organization abstains from doing so itself (for examples, see Tables II-V of the present paper).

[8] There is an immanent tension between the depth (contextuality) and breadth (generalizability) of any theory. The grounded theory methodology tends to generate theories that are highly contextual, but potentially less generalizable than theories generated by other means. We thank an anonymous referee for reminding us of this trade-off.

[9] This mode of inquiry, which consists of double-checking findings by using multiple sources and modes of evidence, has become known as triangulation (Huberman and Miles, 1998). The origin of the term can be traced back to Campbell and Fiske's (1959) 'multiple operationalism' - using multiple measures to ensure that the variance reflected in the dependent variable derives from the influence of the independent variables and not from the measures in use.

[10] See the discussion section of the present paper for a view on where these rules came from.

\section{REFERENGES}

Aldrich, H. E. (1979). Organizations and Environments. Englewood Cliffs, NJ: Prentice-Hall.

Ansoff, H. I. (1980). 'Strategic issue management'. Strategic Management fournal, 1, 131-48.

Berle, A. A. and Means, G. G. (1932). The Modern Corporation and Private Property. New York: Macmillan.

Berman, S. L., Down, J. and Hill, C. W. L. (2002). 'Tacit knowledge as a source of competitive advantage in the national basketball association'. Academy of Management fournal, 45, 13-31.

Blau, P. M. (1955). The Dynamics of Bureaucracy. New York: Random House.

Campbell, D. T. and Fiske, D. W. (1959). 'Convergent and discriminant validation by the multitraitmultimethod matrix'. Psychological Bulletin, 56, 85-105.

Child, J. (1972). 'Organizational structure, environment and performance: the role of strategic choice'. Sociology, 6, 1-22.

Cyert, R. M. and March, J. G. (1963). A Behavioral Theory of the Firm. Englewood Cliffs, NJ: PrenticeHall.

Daft, R. L. and Weick, K. E. (1984). 'Toward a model of organizations as interpretation systems'. Academy of Management Review, 9, 284-95.

Day, G. S. (1994). 'The capabilities of market-driven organizations'. Fournal of Marketing, 58, 37-52.

Demsetz, H. (1991). 'The theory of the firm revisited'. In Williamson, O. E. and Winter, S. (Eds), The Nature of the Firm. New York: Oxford University Press, 159-78.

Dierickx, I. and Cool, K. (1989). 'Asset stock accumulation and sustainability of competitive advantage'. Management Science, 35, 1504-11.

DiMaggio, P. J. and Powell, W. W. (1991). 'Introduction'. In Powell, W. W. and DiMaggio, P. J. (Eds), The New Institutionalism in Organizational Analysis. Chicago, IL: University of Chicago Press, 1-38.

Dutton, J. E. (1993). 'Interpretations on automatic: a different view of strategic issue diagnosis'. Fournal of Management, 30, 339-57.

(The) Economist (1998). 'In defence of the demon seed'. 347, 13-14.

Eisenhardt, K. M. (1989a). 'Agency theory: an assessment and review'. Academy of Management Review, 14, 57-74.

Eisenhardt, K. M. (1989b). 'Building theories from case study research'. Academy of Management Review, 14, 532-50. 
Eisenhardt, K. M. and Sull, D. N. (2001). 'Strategy as simple rules'. Harvard Business Review, 79, $106-16$

Emerson, R. M. (1962). 'Power-dependence relations'. American Sociological Review, 27, 31-40.

Feeny, D. F. and Willcocks, L. P. (1998). 'Core is capabilities for exploiting information technology'. Sloan Management Review, 43, 9-21.

Fombrun, C. J. (1996). Reputation: Realizing Value from the Corporate Image. Cambridge, MA: Harvard Business School Press.

Fombrun, C. J. and van Riel, C. B. M. (1997). 'The reputational landscape'. Corporate Reputation Revierw, 1, 5-13.

Fombrun, C. J. and van Riel, C. B. M. (2004). Fame \& Fortune: How Succesful Companies Build Winning Reputations. Upper Saddle River, NJ: Financial Times/Prentice Hall.

Frey, B. S. (1998). 'Institutions and morale: the crowding-out effect'. In Ben-Ner, A. and Putterman, L. (Eds), Economics, Values, and Organization. Cambridge: Cambridge University Press, 437-60.

Glaser, B. G. and Strauss, A. L. (1967). The Discovery of Grounded Theory: Strategies for Qualitative Research. New York: Aldine de Gruyter.

Gouldner, A. W. (1954). Patterns of Industrial Bureaucracy. Glencoe, IL: Free Press.

Grant, R. M. (1996a). 'Toward a knowledge-based theory of the firm'. Strategic Management Fournal, 17, 109-22.

Grant, R. M. (1996b). 'Prospering in dynamically-competitive environments: organizational capability as knowledge integration'. Organization Science, 7, 375-87.

Grunig, J. E. and Grunig, L. A. (1992). 'Models of public relations and communication'. In Grunig, J. E. (Ed.), Excellence in Public Relations and Communication Management. Hillsdale, NJ: Lawrence Erlbaum Associates, 285-325.

Hall, R. (1992). 'The strategic analysis of intangible resources'. Strategic Management Fournal, 13, 135-44.

Harris, P. and Lock, A. (1996). 'Machiavellian marketing: the development of corporate lobbying in the UK'. Fournal of Marketing Management, 12, 313-28.

Hayek, F. A. (1945). 'The use of knowledge in society'. American Economic Revierw, 35, 519-30.

Heugens, P. P. M. A. R., van den Bosch, F. A. J. and van Riel, C. B. M. (2002). 'Stakeholder integration: building mutually enforcing relationships'. Business \& Society, 41, 37-61.

Hrebiniak, L. G. and Joyce, W. F. (1985). 'Organizational adaptation: strategic choice and environmental determinism'. Administrative Science Quarterly, 30, 336-49.

Huberman, A. M. and Miles, M. B. (1998). 'Data management and analysis methods'. In Denzin, N. K. and Lincoln, Y. S. (Eds), Collecting and Interpreting Qualitative Materials. Thousand Oaks, CA: Sage, $179-210$.

Isabella, L. (1990). 'Evolving interpretations as a change unfolds: how managers construe key organizational events'. Academy of Management fournal, 33, 17-41.

Jacobides, M. G. and Croson, D. C. (2001). 'Information policy: shaping the value of agency relationships'. Academy of Management Reviewe, 26, 202-23.

Jensen, M. C. and Meckling, W. H. (1976). 'Theory of the firm: managerial behavior, agency costs and ownership structure'. Fournal of Financial Economics, 3, 305-60.

Kay, J. A. (1993). Foundations of Corporate Success: How Business Strategies Add Value. Oxford: Oxford University Press.

Lamertz, K., Martens, M. L. and Heugens, P. P. M. A. R. (2003). 'Issue evolution: a symbolic interactionist perspective'. Corporate Reputation Review, 6, 82-93.

Leiss, W. (1994). 'Risk communication and public knowledge'. In Crowley, D. and Mitchell, D. (Eds), Communication Theory Today. Cambridge: Polity Press, 127-39.

Levitt, B. and March, V. (1988). 'Organizational learning'. Annual Review of Sociology, 14, 319-40.

March, J. G. (1981). 'Footnotes to organizational change'. Administrative Science Quarterly, 26, 563-77.

March, J. G. (1994). A Primer on Decision-Making: How Decisions Happen. New York: Free Press.

March, J. G. (1996). 'Continuity and change in theories of organizational action'. Administrative Science Quarterly, 41, 278-87.

March, J. G. and Olsen, J. P. (1984). 'The new institutionalism: organizational factors in political life'. American Political Science Review, 78, 734- 49.

March, J. G. and Olsen, J. P. (1988). 'The uncertainty of the past: organizational learning under ambiguity'. In March. J. G. (Ed.), Decisions and Organizations. Cambridge: Basil Blackwell, 335-58.

March, J. G. and Simon, V. (1958). Organizations. New York: Wiley. 
March, J. G., Schulz, M. and Zhou, X. (2000). The Dynamics of Rules: Change in Written Organizational Codes. Stanford, CA: Stanford University Press.

Merton, R. K. (1957). Social Theory and Social Structure. New York: Free Press.

Merton, R. K., Fiske, M. and Kendall, P. L. (1956). The Focused Interview. Glencoe, IL: Free Press.

Miles, M. B. and Huberman, A. M. (1994). Qualitative Data Analysis: An Expanded Sourcebook. Thousand Oaks, CA: Sage.

Miller, C. (1992). 'Midwest will be test market in '93 for genetically engineered foods'. Marketing Nerws, 26, 1 .

Mills, A. J. and Murgatroyd, S. J. (1991). Organizational Rules: A Framework for Understanding Organizational Action. Philadelphia, PA: Open University Press.

Morrison, E. W. and Milliken F. J. (2000). 'Organizational silence: a barrier to change and development in a pluralistic world'. Academy of Management Review, 25, 706-25.

Nelson, R. R. and Winter, S. G. (1982). An Evolutionary Theory of Economic Change. Cambridge, MA: Harvard University Press.

Nigh, D. and Cochran, P. L. (1987). 'Issues management and the multinational enterprise'. Management International Review, 27, 4-12.

Oliver, C. (1991). 'Strategic responses to institutional processes'. Academy of Management Review, 16, $145-79$.

Oomens, M. J. H. and van den Bosch, F. A. J. (1999). 'Strategic issue management in major European-based companies'. Long Range Planning, 32, 49-57.

Pearson, C. M. and Clair, J. A. (1998). 'Reframing crisis management'. Academy of Management Review, 23, 59-76.

Pentland, B. T. (1995). 'Grammatical models of organizational processes'. Organization Science, 6, $541-56$.

Perrow, C. (1972). Complex Organizations: A Critical Essay. Glenview, IL: Scott, Foresman and Company.

Pettigrew, A. (1988). 'Longitudinal Field Research on Change: Theory and Practice'. Paper presented at the US National Science Foundation Conference on Longitudinal Research Methods in Organizations, Austin, Texas.

Pettit, P. (1996). 'Institutional design and rational choice'. In Goodin, R. E. (Ed.), The Theory of Institutional Design. Cambridge: Cambridge University Press, 54-89.

Polanyi, M. (1962). Personal Knowledge: Towards a Post-Critical Philosophy. New York: Harper Torchbooks.

Popper, K. R. (1934/1959). The Logic of Scientific Discovery. London: Hutchinson.

Powell, D. and Leiss, W. (1997). Mad Cowes and Mother's Milk: The Perils of Poor Risk Communication. Montreal: McGill-Queen's University Press.

Prendergast, C. (1999). 'The provision of incentives in firms'. Fournal of Economic Literature, 37, 7-63.

Priem, R. L. and Butler, J. E. (2001). 'Is the resource-based "view" a useful perspective for strategic management research?'. Academy of Management Review, 26, 22-40.

Rowley, T. J. (1997). 'Moving beyond dyadic ties: a network theory of stakeholder influences'. Academy of Management Review, 22, 887-910.

Schulz, M. (1998). 'Limits to bureaucratic growth: the density dependence of organizational rule births'. Administrative Science Quarterly, 43, 845-76.

Sharma, S. and Vredenburg, H. (1998). 'Proactive corporate environmental strategy and the development of competitively valuable organizational capabilities'. Strategic Management fournal, 19, 729-53.

Simon, H. A. (1955). 'A behavioral model of rational choice'. Quarterly fournal of Economics, 69, 99-118.

Sunstein, C. R. and Ullmann-Margalit, E. (1999). 'Second-order decisions'. Ethics, 110, 5-31.

Thachankary, T. (1992). 'Organizations as "texts": hermeneutics as a model for understanding organizational change'. Research in Organizational Change and Development, 6, 197-233.

Thompson, J. D. (1967). Organizations in Action: Social Science Bases of Administrative Theory. New York: McGraw-Hill.

Tsoukas, H. (1996). 'The firm as a distributed knowledge system: a constructionist approach'. Strategic Management Fournal, 17, 11-15.

Tversky, A. and Kahneman, D. (1974). 'Judgments under uncertainty: heuristics and biases'. Science, 185, $1124-31$.

Useem, M. and Harder, J. (2000). 'Leading laterally in company outsourcing'. Sloan Management Review, 41, 25-36. 
van de Ven, A. H., Delbecq, A. L. and Koenig, R. (1976). 'Determinants of coordination modes within organizations'. American Sociological Review, 41, 322-38.

Walsh, J. (1999). 'Brave new farm'. Time, 153, 86-8.

Warnock, G. J. (1971). The Object of Morality. London: Methuen \& Co.

Weick, K. E. (1979). The Social Psychology of Organizing. New York: McGraw-Hill.

Weick, K. E. (1998). 'Improvisation as a mindset for organizational analysis'. Organization Science, 9, 543-55.

Whetten, D. A. and Mackey, A. (2002). 'A social actor conception of organizational identity and its implications for the study of organizational reputation'. Business \& Society, 41, 393-414.

Winter, S. G. (1986). 'The research program of the behavioral theory of the firm: orthodox critique and evolutionary perspective'. In Gilad, B. and Kaish. S. (Eds), Handbook of Behavioral Economics. Greenwich, CT: JAI Press, 151-88.

Winter, S. G. (2000). 'The satisficing principle in capability learning'. Strategic Management Journal, 21, 981-96.

Yin, R. K. (1994). Case Study Research: Design and Methods. Thousand Oaks, CA: Sage. 
Copyright of Journal of Management Studies is the property of Blackwell Publishing Limited and its content may not be copied or emailed to multiple sites or posted to a listserv without the copyright holder's express written permission. However, users may print, download, or email articles for individual use. 